\title{
Against a Federal Patients' Bill of Rights
}

\author{
Edward A. Zelinsky ${ }^{\dagger}$
}

\section{INTRODUCTION}

The failure of the 107th Congress to pass a "Patients' Bill of Rights" (PBR) is widely considered a major disappointment, ${ }^{1}$ to be remedied in the 108 th Congress by the adoption of such legislation. Indeed, federal PBR proposals have achieved the proverbial motherhood-and-apple-pie status; it is virtually impossible to find anyone actively opposing a federal PBR. Many members of the 108th Congress likely feel pressure to pass PBR legislation before returning to the electorate in 2004.

I advance a contrary perspective: A federal PBR is an idea whose time is past or, to be precise, is an idea whose rationales are no longer persuasive. We should neither mourn the failure of the 107th Congress to adopt a federal PBR, nor should we encourage the 108th Congress to enact such legislation.

The original justification for a PBR arose from the Employee Retirement Income Security Act of 1974 (ERISA) ${ }^{2}$ and its preemption provision, section 514. For many years, ERISA section 514 was interpreted to displace state regulation of medical care provided via employer-sponsored plans. Since ERISA itself supplies no regulation to replace the state regulation ERISA was believed to preempt, there appeared to be a "regulatory gap." Within this gap, health

$\dagger$ Edward A. Zelinsky is professor of law at the Benjamin N. Cardozo School of Law of Yeshiva University. For their comments on prior drafts, he thanks Professors Jonathan Barry Forman, John H. Langbein and Jerry L. Mashaw; the participants in the Cardozo faculty workshop; Attorney Alvin D. Lurie; Cardozo students Pearl S. Basch, Steven Platzek and Vivian Williams; and Doris Zelinsky.

1. See, e.g., Robert Pear, White House and Senate Hit Impasse on Patients' Rights, N.Y. TIMES, Aug. 2, 2002, at A 17; Morton Kondracke, Underachieving Congress Will Eventually Compromise, NEw HAVEN REGISTER, October 20, 2002, at B3 ("Probably the starkest area of failure is in the health field. The lawyer issue has torpedoed patients" rights legislation.").

2. Employee Retirement Income Security Act of 1974 ("ERISA"), Pub. L. No. 93-406, 88 Stat. 829 (1974) (codified as amended at 29 U.S.C. $\$ \S 1001-1381(2000)$ ).

3. See, e.g., Gary A. Francesconi, ERISA Preemption of 'Any Willing Provider' Laws - An Essential Step Toward National Health Care Reform, 73 WASH. U. L.Q. 227, 236 (1995) ("ERISA's preemption clause thus creates a regulatory gap in areas such as health care insurance benefits where federal statutes do not address some of the major regulatory issues."); Lizzette Palmer, ERISA Preemption and Its Effects on Capping The Health Benefits of Individuals with AIDS: A Demonstration of Why The United States Health and Insurance Systems Require Substantial Reform, 30 HOUSTON L. REV. 1347, 1381 n.240 (1993) ("the regulatory gap created by ERISA preemption"); Dennis K. Schaeffer, Insuring the Protection of ERISA Plan Participants: ERISA Preemption and the Federal Government's Duty To Regulate Self-Insured Health Plans, 47 BufFALO L. REV. 1085, 1095 (1999) ("The states found that 
maintenance organizations (HMOs) and other managed care organizations operated free of legal constraints and liabilities when such health care providers serviced employer plans. It was argued that this regulatory gap left employees at the mercy of HMOs and the other managed care entities that today furnish most employer-based medical care. The resulting images-patients being subjected to medical malpractice without remedies due to ERISA's preemption of state tort law, arrogant HMOs operating beyond regulation-packed significant political wallop.

However, the original defense of a federal PBR has been undermined by the subsequent evolution of the case law of the U.S. Supreme Court. That case law today construes ERISA section 514 as generally permitting state regulation of HMOs and similar medical care providers, both statutorily and via malpractice liability rules, even when such providers service employers' medical plans. Thus, there is no longer a regulatory gap and no need for federal legislation in the form of a PBR to fill the void. ${ }^{4}$

The second argument for a PBR is the need for national uniformity in the regulation of medical care - uniformity which only federal legislation can ensure. This argument was never strong as it ignores the benefits of decentralization in the regulation of health care: increased experimentation and accommodation of diverse preferences. In any event, Congress's unwillingness to pass a PBR which provides genuine uniformity throughout the nation eroded the national uniformity argument for a federal PBR.

The final rationale for a federal PBR is the alleged desirability of a national floor in the provision of medical care, below which states may not fall or experiment - depending upon one's perspective. However, I suggest that the advocates of a federal PBR have not and cannot articulate a convincing rationale for such a floor. There is no evidence in the health care arena of the proverbial race to the bottom, justifying a national floor, nor is there reason to believe such a race to the bottom will occur in health care. Indeed, it is difficult to imagine the floor defense, had it been the original justification for a PBR, propelling that proposal to the prominence it enjoys today.

In short, the federal PBR is today a program in search of a rationale, a prominent part of the national agenda because of historical circumstances rather than any currently compelling justification. Moreover, a federal PBR would impose two kinds of costs on an already burdened medical system. A PBR would increase administrative and legal complexity while reducing the states' flexibility to experiment and innovate. No apparent benefits would justify these

ERISA prevented them from stepping into the regulatory gap that ERISA had created.").

4. As I discuss infra Part IV, there is an argument for amending ERISA to permit the states' regulation of health maintenance organizations to apply to employers' self-funded medical plans. It might also be necessary to make narrow amendments to specific parts of ERISA. However, such relatively modest legislation is a far cry from the broad federalization of health care regulation which would be effectuated by a federal patients' bill of rights. 
costs, which at the margin will cause some employers (particularly small employers) to drop medical coverage for their employees. Consequently, it is time to scrap the notion of a federal PBR.

The first Part of this Article explores the history of the PBR concept, starting with ERISA and its preemption provision, ERISA section 514. This history is critical to understanding the paradox that today the PBR is widely believed to be of great importance, despite lacking persuasive justification. The original circumstance underpinning proposals for a federal PBR - the U.S. Supreme Court's initial, expansive understanding of ERISA preemption-has changed, undercutting the first and strongest rationale for a PBR, the regulatory gap thesis.

Part II of this Article focuses upon the Supreme Court's recent decision on ERISA preemption, Rush Prudential HMO, Inc. v. Moran. ${ }^{5}$ Moran confirms a legal environment different from the historical context from which proposals for a federal PBR emerged: States can generally regulate medical care providers, via statute and malpractice liability rules, even when such providers service employer-sponsored plans. Thus, there is no longer an ERISA-created regulatory gap requiring federal intervention in the form of a PBR.

In Part III, I explore and reject the alternative rationales for a PBR-the need for national uniformity in the provision of medical care and the need for a national floor for such care. Upon examination, neither justification proves compelling. Moreover, a PBR would engender costs in terms of complexity and inflexibility.

The final Part of this Article addresses one area where there is a case for further federal legislation. In particular, a plausible argument can be advanced that Congress should amend ERISA to permit states to extend to employers' self-funded medical plans the same state regulation which applies to insured plans, including employer-engaged HMOs. Such relatively modest legislation (which would expand the compass of state, not national, regulation) stands in sharp contrast to a federal PBR.

In sum, a federal PBR is today a program in search of a rationale. Originally conceived to fill an ERISA-created regulatory gap, no such gap remains under the Court's current understanding of ERISA section 514. Thus there is no justification for a PBR under this initial, preemption-based rationale. Congress has made clear that a PBR will not provide national uniformity, even assuming such uniformity is desirable. As a floor underneath states' regulation of health care, a PBR would respond to a nonexistent problem, a race to the bottom. On the cost side of the ledger, a PBR would generate complexity in the law governing health care while inhibiting the states from experimenting and innovating. In the final analysis, a federal PBR is an idea whose time is past.

5. 122 S. Ct. 2151 (2002). 


\section{ERISA AND PREEMPTION: A BRIEF HISTORY}

To the uninitiated, it may seem anomalous that the federal legislation regulating pensions and profit-sharing plans ("employee retirement income") should also cover employer-provided fringe benefit programs. In many respects, these are quite different arrangements. Pensions and profit-sharing plans defer wage income into the future. In contrast, fringe benefit programs typically provide current emoluments such as medical insurance or disability coverage. Nevertheless, for reasons of policy and politics, ERISA regulates both retirement income programs and most fringe benefit arrangements, but regulates them quite differently. ERISA governs pension and profit-sharing plans extensively and in detail, while ERISA's regulation of fringe benefits is more limited.

A number of ERISA's provisions apply to both pension and profit-sharing plans and to fringe benefit arrangements (denoted in the statute as "employee welfare plans"). ${ }^{6}$ For example, the ERISA provisions requiring disclosure of information to participants and to the federal government apply to both kinds of plans. ${ }^{7}$ Similarly, for both types of plans, ERISA mandates internal claims procedures $^{8}$ and establishes judicial remedies for aggrieved participants. ${ }^{9}$ Likewise, the fiduciary portions of ERISA, ${ }^{10}$ which outline standards of conduct for those managing plans and plan assets, ${ }^{11}$ apply to both the fiduciaries of retirement income arrangements and to the fiduciaries of fringe benefit plans.

However, ERISA provides heavy regulation of the contents of pension and profit sharing plans but has no comparable regulation of fringe benefits. Thus, ERISA mandates elaborate rules as to the coverage of retirement income programs, ${ }^{12}$ vesting schedules for such programs, ${ }^{13}$ the forms in which retirement benefits must be paid, ${ }^{14}$ funding standards for pension plans, ${ }^{15}$ and FDIC-type insurance for the basic benefits provided by most defined benefit pension plans. ${ }^{16}$ ERISA, however, does not govern fringe benefit programs in equivalent fashion.

6. ERISA § 3(1).

7. ERISA $\S \S 101-111$.

8. ERISA $\S 503$.

9. ERISA $\S 502$.

10. ERISA $\S 404$.

11. For ERISA's expansive definition of a plan fiduciary, see ERISA § 3(21)(A).

12. ERISA § 202. For parallel provisions of the tax code, see I.R.C. $\S 410$ (2002).

13. ERISA § 203. For parallel provisions of the tax code, see I.R.C. $\$ 411$ (2002).

14. ERISA $\S \S 205$ and 206. For parallel provisions of the tax code, see I.R.C. $\S \S 401(a)(11), 417$, 401(a)(14), 401(a)(15), 401(a)(13) and 414(p).

15. ERISA § 302. For parallel provisions of the tax code, see I.R.C. $\S 412$. Significantly, there are no funding standards for profit sharing plans, an important reason that employers are switching to such plans and their greater funding flexibility. See Edward A. Zelinsky, ERISA and the Emergence of the Defined Contribution Society, NYU 57TH INSTITUTE ON FEDERAL TAXATION- EMPLOYEe BENEFITS AND EXECUTIVE COMPENSATION 6-2 to 6-11 (1999) [hereinafter Zelinsky, Defined Contribution Society].

16. ERISA $\S \S 4001-09$. 
The most significant provision of ERISA applying to both the universe of pension and profit-sharing plans and to the world of fringe benefits is ERISA section 514, which provides that ERISA "shall supersede any and all state laws as they may now or hereafter relate to any employee benefit plan"17 covered by ERISA. This preemption mandate is qualified by the reservation that ERISA does not supersede states' laws as to insurance, securities, banking or general criminal codes. ${ }^{18}$

With the benefit of hindsight, it is apparent that the addition of section $514^{19}$ to ERISA has had radically different implications for pension and profitsharing plans (heavily regulated by ERISA) than for fringe benefit plans (less regulated by ERISA). Given the elaborate nature of ERISA's provisions pertaining to retirement income arrangements, even absent section 514, state laws intruding upon pension and profit-sharing arrangements would largely have been preempted anyway under the normal rules for federal preemption of state law, since ERISA occupies the regulatory field to the exclusion of state law. ${ }^{20}$ In contrast, section 514 created the possibility of a regulatory gap as to fringe benefit programs since section 514 preempts state law even when ERISA supplies no regulation of such programs.

A regulatory gap can be characterized more positively as a zone of employer autonomy. ${ }^{21}$ Nevertheless, proposals for a federal PBR were fueled by the perception that ERISA section 514 placed beyond effective state and federal regulation HMOs and other managed care organizations providing employer-based medical care. The resulting regulatory gap was perceived as inimical to the interests of the employees and their families serviced by such organizations. Moreover, the images of the regulatory gap were politically potent: medical malpractice victims without remedies since ERISA preempted state tort law without providing any replacement; arrogant HMOs beyond the reach of any law since, again, ERISA displaced state regulation without supplying any substitute. ${ }^{22}$

17. ERISA $\S 514$ (a). ERISA uses the term "employee benefit plan" to refer to both fringe benefit and retirement income plans. See ERISA $\S 3(3)$.

18. ERISA $\S \S 514(\mathrm{~b})(2)(\mathrm{A}), 514(\mathrm{~b})(4)$.

19. On the background of section 514, see JOIN H. LANGBEIN \& BRUCE A. WOLK, PENSION AND EMPLOYEE BENEFIT LAW 498-502 (3rd ed. 2000).

20. See Edward A. Zelinsky, Travelers, Reasoned Textualism, and the New Jurisprudence of ERISA Preemption, 21 CARDOzo L. REV. 807, 858-864 (1999) [hereinafter Zelinsky, Reasoned Textualism]. See also, Edward A. Zelinsky, Reasoned Textualism and ERISA Preemption: An Overview, NEW YORK UNIVERSITY 57TH INSTITUTE ON FEDERAL TAXATION 12-3 to 12-5 (1999) [hereinafter Zelinsky, Overview].

21. Zelinsky, Reasoned Textualism, supra note 20, at 812 .

22. See, e.g., Amy Goldstein \& Terry M. Neal, On The Road, Away From Crisis: Clinton's Pitch on Health Care Reflects Lessons Learned in '94, WASH. POST, Aug. 11, 1998, at A1 ("The public's anger at HMOs and eagemess for government action has made the issue irresistible even to reluctant Republicans, who are accustomed to dismissing Democratic ideas for regulating private industry as "big government."”). 
For a decade, the U.S. Supreme Court construed section 514 in a fashion that confirmed the existence of an ERISA-created regulatory gap for fringe benefit programs in general and for employer-provided medical coverage in particular. Starting with Shaw v. Delta Air Lines ${ }^{23}$ and ending with District of Columbia v. Greater Washington Board of Trade, ${ }^{24}$ the Court held that section 514 preempted a broad array of state laws on the ground that such laws had "a connection with" or "refer[red] to" ERISA-governed plans. ${ }^{25}$ During the period in which the Supreme Court understood section 514 capaciously, ${ }^{26}$ many lower courts, quite reasonably, inferred from the Supreme Court's case law that section 514 displaced state malpractice laws and state statutes regulating HMOs and other managed care providers insofar as such malpractice and managed care laws "relate[d] to" employer-sponsored health plans. ${ }^{27}$

It was during this period that proposals for a federal PBR garnered their initial support as employer-provided medicine increasingly took the form of HMOs and other managed care coverage (rather than traditional indemnity insurance) ${ }^{28}$ Given the apparent regulatory gap created by ERISA section 514 under Shaw and its progeny, a federal PBR became a rallying cry for those seeking both to regulate managed care providers even when such providers service employer-sponsored plans and to extend malpractice rules to medical care providers hired by such employer-sponsored plans.

A legislative response to the regulatory gap could have taken a variety of forms. Congress could have repealed section 514, thereby reducing ERISA's preemptive force to accommodate state malpractice and HMO laws. Alternatively, Congress could have augmented the existing exemptions under section 514, making explicit that section 514 does not preempt state tort laws or state regulation of HMOs, but otherwise leaving section 514 intact. Instead, the comprehensive $^{29}$ response that gathered political and legislative momentum was a federal PBR, amending ERISA to regulate medical care coverage just as

23. 463 U.S. 85 (1983).

24. 506 U.S. 125 (1992).

25. Shaw, 463 U.S. at $96-97$.

26. This period is discussed in Zelinsky, Reasoned Textualism, supra note 20, at 815-27.

27. Id. at $854-58$.

28. See, e.g., Joanne Wojick, Preadmission Tests Most Popular Tool in Controlling Costs, BUSINESS INSURANCE, Jan. 21, 1991, at 3 ("Health maintenance organizations were used by $67 \%$ [of surveyed employers] in 1990 , up from $62 \%$ in $1988 . "$ ).

29. During this period, Congress enacted more limited responses to perceived problems with employer-provided medical care. The so-called "COBRA" provisions protect employees and their beneficiaries when they lose employer-provided coverage. In particular, the COBRA rules allow such employees and beneficiaries to purchase continued coverage for a transition period. In addition, other statutory provisions, denoted "portability" rules, facilitate employer-based coverage by, inter alia, limiting preexisting condition exclusions and prohibiting discrimination based on an individual's health status. See ERISA $\S 601$ (COBRA), I.R.C. $\S 4980$ B (tax version of COBRA provisions), ERISA $\S 701$ (portability rules), and I.R.C. $\$ \$ 4980 \mathrm{D}, 9801$ (tax version of portability rules). These limited arrangements did not diminish support for more comprehensive PBR legislation. 
ERISA governs the content of pension and profit-sharing arrangements. ${ }^{30}$ Indeed, in the 107th Congress, the House and Senate each passed separate versions of a PBR, although the conference committee failed to reconcile the two versions for final action. ${ }^{31}$ This legislation, had it been enacted into law, would have mandated in great detail both the substance of the medical care offered by provider organizations (e.g., access to types of care and medicines including treatment by particular types of caregivers) and the procedural remedies available to aggrieved patients (e.g., internal and external review processes). ${ }^{32}$

However, in the midst of debate about a PBR, the Supreme Court curtailed the scope of section 514 and ERISA preemption. ${ }^{33}$ The key decision was $\mathrm{New}$ York State Conference of Blue Cross \& Blue Shield Plans v. Travelers Insurance $\mathrm{Co}^{34}$ in which the Court upheld New York's scheme of hospital rate regulation even though such regulation affected ERISA plans. State laws with only "indirect economic influence",35 on ERISA-regulated arrangements, the Travelers Court held, are not preempted by section 514 .

While the Court has been reluctant to acknowledge the extent to which Travelers departed from Shaw, the departure is marked. Subsequent decisions have confirmed that Travelers was no aberration but, rather, inaugurated a more restricted understanding of section 514 and ERISA preemption. Notably, in Pegram v. Herdrich, ${ }^{36}$ all nine members of the court joined an opinion indicating that section 514 does not preempt state malpractice laws when medical care is provided pursuant to an employer-sponsored plan. ${ }^{37}$ While these comments are dicta, they are consistent with the more limited assessment of ERISA preemption announced in Travelers.

In simplest terms, the regulatory gap resulting from the conjunction of a broad interpretation of ERISA preemption and ERISA's silence on the substance of employee welfare programs no longer exists in light of the Supreme Court's newer, narrower construction of section 514 and of ERISA's preemptive force. Since it was this regulatory gap that originally impelled the movement for a federal PBR, the disappearance of that gap eroded the initial and strongest rationale for a PBR.

30. Particularly critical to the evolution of federal PBR proposals was the Norwood-Dingell bill. See Edward A. Zelinsky, Norwood-Dingell, ERISA Preemption, and Unintended Consequences, 85 TAX NOTES 1669 (Dec. 27, 1999).

31. See H.R. 2563, $107^{\text {th }}$ Cong. (2001); S 872, 107th Cong. (2001).

32. A federal PBR would not extend medical coverage to anyone, but would merely regulate the terms on which coverage must be given to those who have it. Indeed, as I discuss infra, a federal PBR, by increasing the cost of employer-provided health care, might, at the margin, cause some employers (particularly smaller ones) to cease providing such care.

33. Zelinsky, Reasoned Textualism, supra note 20, at 827-39.

34. 514 U.S. 645 (1995).

35. Id. at 660 .

36. 530 U.S. 211 (2000).

37. See Edward A. Zelinsky, Pegram and Preemption: Patients' Rights and the Case for Doing Nothing, 88 TAX NOTES 1053 (Aug. 21, 2000). 


\section{THE MORAN DECISION}

Even after the Court's unanimous statement in Pegram affirming the applicability of state malpractice laws to employer-sponsored medical care, there remained the possibility that the Court, confronting squarely the legality of state statutes regulating HMOs, would revert to its original, more expansive, Shaw-based understanding of ERISA preemption and strike such state HMO statutes as incompatible with section 514 in the context of HMOs servicing employer-sponsored plans. However, in Moran, the Court confirmed its Travelers mindset and, with four justices dissenting, ${ }^{38}$ sustained an Illinois law regulating HMOs and other managed care providers even when such providers service employer-sponsored plans.

The facts in Moran are typical of the disputes that arise between HMOs and the individuals they serve. Mrs. Moran was covered by the medical plan sponsored by her husband's employer. That plan contracted with Rush Prudential HMO, Inc. ("Rush") to render care to covered employees and their dependents. When Mrs. Moran developed "pain and numbness in her right shoulder," became dissatisfied with the care prescribed by Rush and sought alternative treatment that Rush denied. Section 4-10 of the Illinois statute regulating HMOs entitled Mrs. Moran to an independent review of Rush's decision to deny her this alternative treatment. When Mrs. Moran requested such review, Rush declined to comply with section 4-10 and its review procedure, claiming that ERISA preempts these state law provisions. ${ }^{40}$ Mrs. Moran obtained the treatment she sought and sued, demanding that Rush reimburse her for the cost of that treatment.

Meanwhile, the Illinois courts ordered Rush to comply with the independent review procedure mandated by section 4-10. While the independent reviewer decided that the alternative treatment pursued by Mrs. Moran was medically appropriate, Rush continued to disagree and refused to reimburse Mrs. Moran's costs. The U.S. Supreme Court, over four dissents, decided for Mrs. Moran, holding that the independent review procedure established by section 410 of the Illinois HMO statute is not preempted by ERISA section 514(a) but is instead a permitted state regulation of insurance, protected from preemption by section 514(b)(2)(A)'s exemption for state insurance laws.

HMOs, the Moran Court held, serve two functions: They provide medical care and spread risk. Risk spreading is a hallmark of insurance. As a result of the risk-spreading "insurance features" 41 of Rush and other HMOs, state stat-

38. As I discuss infra, there is greater agreement among the nine justices than their 5-4 split initially suggests.

39. Moran, 122 S. Ct. 2151,2156 (2002).

40. Id. at 2157 ("Rush removed [Mrs. Moran's] suit to Federal District Court, arguing that the cause of action was 'completely preempted' under ERISA.").

41. Id. at 2162 . 
utes regulating HMOs regulate insurance and, as such, fall within the statutory exclusion from ERISA preemption. Furthermore, the Court noted, section 4-10 is "something akin to a mandate for second-opinion practice in order to ensure sound medical judgments," 42 far removed from the "judicial enforcement" provisions of ERISA section 502 which prescribe an aggrieved participant's remedies against an ERISA-governed plan.

Moran is not without its doctrinal problems. Most importantly, Moran (like the Court's other post-Travelers decisions) does not acknowledge the tension between the expansive Shaw framework and the more limited conception of ERISA preemption embraced in Travelers. On the one hand, Moran, in the spirit of Shaw, declares that "[i]t is beyond serious dispute that under existing precedent section 4-10 of the Illinois HMO Act 'relates to' employee benefit plans within the meaning of" ERISA section $514(\mathrm{a}) .{ }^{43}$ On the other hand, Moran suggests, in the more circumspect spirit of Travelers, that "[i]n the field of health care, a subject of traditional state regulation, there is no ERISA preemption without clear manifestation of congressional purposes." 44 These two propositions ultimately collide. Under section 514(a), state laws relating to ERISA-governed plans are preempted unless they fall within one of the excepted categories of state statutes - which health care regulation does not. As a statutory matter, state health care laws avoid section 514(a) only if they do not relate to employer-sponsored plans.

Moran avoids this tension by characterizing the Illinois HMO law as protected from ERISA preemption by the statutory exemption for state insurance laws. ${ }^{45}$ This move is plausible and even accepted (at least on an arguendo basis) by the Moran dissenters. ${ }^{46}$ However, the tension remains and will become acute when the Court confronts a case which challenges a state statute that regulates medical care without falling within one of the enumerated exceptions of section 514.

For purposes of evaluating the need for a federal PBR, the logic of Moran is less important than Moran's result: ERISA does not preempt state regulation of HMOs. Indeed, this result was more widely endorsed by the Supreme Court than is first suggested by the Moran Court's 5-4 split. The four Moran dissenters, while rejecting what they characterized as improper state supplementation of Mrs. Moran's ERISA-based procedural remedies, indicated that states can regulate HMOs substantively.

The Moran dissenters rejected the majority's characterization of section 4-

42. Id. at 2169 .

43. Id. at 2159 .

44. Id. at 2171. ("[T] he historic police powers of the States were not [meant] to be superseded by the Federal Act unless that was the clear and manifest purpose of Congress.") Id. at 2159.

45. ERISA $\S 514(b)(2)(A)$.

46. Moran, 122 S.Ct. at $2172 \mathrm{n} .1$ ("I would assume without deciding that 215 Ill. Comp. Stat., ch. 125 , Section 4-10 (2000) is a law that "regulates insurance."'). 
10 as merely mandating a second medical opinion and, instead, viewed that provision as an "arbitration-like mechanism to settle benefits disputes" inconsistent with ERISA section 502 and the judicial remedies that section 502 gave Mrs. Moran. From this premise, the dissenters concluded that state regulation of HMOs cannot supplement ERISA's remedy provisions.

However, the dissenters did not reject all state regulation of HMOs. Indeed, writing for himself and his three other dissenting colleagues, Justice Thomas made clear that, while ERISA in his reading of the statute preempts state laws (like section 4-10) purporting to establish procedural remedies against HMOs, states' substantive regulation of HMOs and their operations does not violate ERISA:

Indeed, were a State to require that insurance companies provide all "medically necessary care" or even that it must provide a second opinion before denying benefits, I have little doubt that such substantive requirements would withstand ERISA's preemptive force. ${ }^{47}$

Thus, one way of characterizing Moran is that a bare majority of the Court sustained all $^{48}$ state regulation of HMOs as permitted regulation of insurance while the entire Court agreed that states may regulate HMOs substantively. As a result, the Court has closed the regulatory gap created by ERISA's preemption of state law. After Moran, states can, notwithstanding ERISA and section 514 , regulate HMOs and other managed care providers engaged by employers. By closing the ERISA-created regulatory gap, the Court has eliminated the initial and strongest rationale for a federal PBR governing employer-provided health care, i.e., the need for the federal government to regulate because the states cannot.

Consider in this context a thought experiment: Suppose that there had never been the expansive understanding of section 514 first articulated in Shaw but that, instead, the Supreme Court had embraced $a b$ initio the more restrained Travelers approach to ERISA preemption. Suppose further that Pegram and

47. Id. at 2177.

48. The Moran majority suggested that there might be state regulation which would run afoul of section 502--but that this was not it. Id. at $2168 \mathrm{n} .11$ ("We recognize, of course, that a State might enact an independent review requirement with procedures so elaborate, and burdens so onerous, that they might undermine [section 502(a)]. No such system is before us.")

This observation leaves for the future the resolution of whether HMOs and other managed care organizations can be required to pay consequential or punitive damages for their faulty decisions. See, Richard A. Epstein and Alan O. Sykes, The Assault on Managed Care: Vicarious Liability. ERISA Preemption, and Class Actions, 30(2) J. LEGAL STUD. 625, 632 (2001).

On the one hand, ERISA section 502 does not provide for such damages. On the other hand, a plausible reading of Moran is that states can authorize such damages, judicially or legislatively, as part of their regulation of insurance, including HMOs. As one persuaded of the value of decentralized decisionmaking and experimentation in this area, I prefer the latter understanding of the law and predict that the Moran majority will agree when it must decide the issue.

Some may favor consequential or punitive damages for HMOs and other managed care providers but believe that, even after Moran, section 502 precludes such damages. For them, the logical alternative is the amendment of section 502 . 
Moran had come early in the Court's development of its ERISA preemption case law. In this alternative world, as medical care in general and HMOs in particular became matters of national concern, it would have been clear that state malpractice laws generally apply to the medical mistakes of employer-engaged HMOs. It also would have been clear that states can regulate HMOs even when HMOs are hired by employers' health care plans.

In this hypothetical world, there would have been no cry for a PBR to fill the ERISA-created regulatory gap since there never would have been such a gap to fill. The rhetoric and images which fueled demand for a PBRmalpractice victims without remedies, HMOs immune from regulation-never would have arisen. In this alternative world, it is unlikely that the concept of a federal PBR would have been born and it is certain that that concept never would have reached the prominence it enjoys today.

Even after Travelers, Pegram, and Moran, important issues about the relationship between ERISA preemption and states' regulation of medical care remain. For example, the U.S. Supreme Court has recently rejected an ERISA challenge to Kentucky's "any willing provider" statute, which requires a health plan to engage and pay for any medical professional prepared to accept the terms of such a plan. ${ }^{49}$ This decision raises as many interpretive issues as it settles. Similarly, the scope of ERISA section 502's preemptive effect remains to be determined. ${ }^{50}$ It is, for example, not always clear when an HMO has made a medical decision (subject to state malpractice laws) and when the HMO has made a benefit determination (governed by section 502's remedial scheme). ${ }^{51}$ In yet other respects, at least some Courts of Appeals have been reluctant to implement fully the teachings of Travelers, Pegram, and Moran. ${ }^{52}$

While I do not minimize the importance of these issues, they reflect, at most, the need for comparatively minor amendments to specific parts of ERISA rather than the broad federalization of medical care regulation which a PBR would represent. Whatever the ultimate contours of the Travelers-PegramMoran case law, there is now no doubt that states can, in general, regulate

49. Kentucky Ass'n of Health Plans v. Miller, 2003 U.S. Lexis 2710 (2003). The Court in Kentucky Association propounded a new, two-part test to determine if a state law regulates insurance and thus survives ERISA preemption. Under that test, a "state law must be specifically directed toward entities engaged in insurance" and "the state law must substantially affect the risk pooling arrangement between the insurer and the insured." Critical elements of this test, such as the specificity with which a state law regulates insurance and the substantiality of the impact of such law, are not self-defining and will require further explication.

50. For example, as I discuss supra note 48 , some courts and commentators have questioned whether, in light of ERISA section 502, HMOs and other managed care organizations can be required to pay consequential or punitive damages for their faulty decisions.

51. Compare Haynes v. Prudential Health Care, 313 F.3d 330 (5th Cir. 2002) with Cicio v. Does 18, 2003 U.S. App. Lexis 2925 (February 11, 2003).

52. See, e.g., Roark v. Humana, Inc., 307 F.3d 298 (5th Cir. 2002) ("If we were writing on a clean slate, or deciding this en banc, the Roarks would have a strong case against ERISA preemption."); Cicio, 2003 U.S. App. Lexis at 37 ("We conclude, largely on the basis of recent Supreme Court decisions, that such a state law claim is not preempted."). 
HMOs and apply their malpractice laws when patients receive substandard care from HMOs - even when such HMOs are engaged by employer plans. Hence, even though questions remain about the scope of ERISA preemption, the "regulatory gap" underpinning federal PBR proposals has disappeared-and, with that disappearance, the strongest rationale for a federal PBR has also vanished.

\section{THE ALTERNATIVE RATIONALES: UNIFORMITY AND A FLOOR}

Although the original rationale for a federal PBR is no longer compelling, alternative rationales might still justify such legislation. The strongest alternative argument for a PBR is the asserted need for national uniformity in employer-financed health care.

National uniformity is often proclaimed as a fundamental goal of ERISA. For example, in Egelhoff v. Egelhoff, ${ }^{53}$ the Supreme Court, heavily influenced by uniformity considerations, struck down as to ERISA-governed plans a Washington State statute which, on divorce, revokes nonprobate beneficiary designations of the former spouse. Writing for the Court, Justice Thomas emphasized considerations of national uniformity:

The Washington state statute also has a prohibited connection with ERISA plans because it interferes with nationally uniform plan administration. One of the principal goals of ERISA is to enable employers to "establish a uniform administrative scheme, which provides a set of standard procedures to guide processing of claims and disbursement of benefits." Uniformity is impossible, however, if plans are subject to different legal obligations in different States. ${ }^{54}$

The case for national uniformity in the regulation of employee benefits is strongest in the context of retirement income arrangements maintained by multistate employers for mobile work forces since retirement income accrues cumulatively over the course of the employee's career. Consider, for example, $\mathrm{Z}$, a national corporation with a facility in each of states $\mathrm{A}, \mathrm{B}$, and $\mathrm{C}$ and a defined contribution pension plan which covers employees at all three facilities. Suppose further that employee $X$ works for $Z$ first in $A$, then in $B$, and finally in $C$ and then leaves $Z$ 's employment well before his sixty-fifth birthday. The questions arise: To what extent is $X$ vested in the pension benefits he earned while employed by $Z$ and, conversely, to what extent (if any) does $X$ forfeit his pension benefits since he left employment with $Z$ before normal retirement age?

Under ERISA's nationwide vesting scheme, ${ }^{55}$ this inquiry has a relatively

53. Egelhoff v. Egelhoff, 532 U.S. 141 (2001). See Edward A. Zelinsky, Egelhoff, ERISA Preemption, and the Conundrum of the "Relate To" Clause, 91 TAX NOTES 1917 (June 11, 2001), for a discussion of Egelhoff.

54. 532 U.S. at 148 (quoting Fort Halifax Packing Co. v. Coyne, 482 U.S. 1 (1987)) (citation omitted). Justice Thomas has been particularly outspoken in proclaiming the national uniformity concerns which underlie ERISA. His dissent in Moran is heavily premised on such uniformity considerations. He argues that Moran "eviscerates the uniformity of ERISA remedies." Moran, $122 \mathrm{~S}$. Ct. at 2172.

55. ERISA $\S 203$. The parallel provision of the tax code is I.R.C. $\S 411$. For discussion of ERISA's 
simple and simply determined answer. ${ }^{56} \mathrm{X}$ 's years of employment with $\mathrm{Z}$ are counted and then compared with the ERISA-regulated vesting schedule of Z's plan. For example, $\mathrm{Z}$ may have adopted ERISA's so-called "cliff" standard for vesting, i.e., employees are fully vested in their pension benefits after completing five years of service, with no vesting before then. ${ }^{57}$ If, consequently, $X$ has completed five or more years of service for $\mathrm{Z}, \mathrm{X}$ is fully vested in the pension he has earned and his termination of employment triggers no loss of pension benefits. If, on the other hand, $Z$ uses cliff vesting and $X$ has less than five years of service, $X$ is vested in none of his pension as he has not scaled the cliff. Consequently, $\mathrm{X}$ forfeits his entire pension benefit when he leaves employment with $Z$.

To consider another variation, suppose that $Z$, in lieu of cliff vesting, has adopted the kind of graded vesting schedule permitted by ERISA. ${ }^{58}$ Under this alternative, each additional year of service generates more vesting. Thus, in our example the number of X's years of service determines the percentage of his benefit to which he has a nonforfeitable right. If, for instance, $X$ has worked for $Z$ for a total of six years and $Z$ has adopted ERISA's graded vesting scheme, $X$ is vested in eighty percent of his pension and forfeits the remainder when he terminates his employment. On the other hand, if $\mathrm{X}$ has worked for $\mathrm{Z}$ for only four years, $X$ is vested in only forty percent of his pension and consequently forfeits a larger balance.

Contrast these nationally uniform schemes with the possibility that each state might have its own (potentially conflicting) vesting rules. Suppose, for example, that vesting were regulated by the states; that state $A$ were to vest on a "cliff" basis, i.e., full vesting on the attainment of a specified number of years with no prior vesting before then; that state B were to vest on a graded basis, i.e., vesting percentages increase with years of service; and that state $\mathrm{C}$ were to provide for no vesting if the employee leaves employment prior to normal retirement at age 65 .

In this hypothetical world, when $\mathrm{X}$ leaves the employment of $\mathrm{Z}$, matters are significantly more complicated than under ERISA's national vesting standard. Initially, there is the conflict of laws question: Which state's vesting rules apply? One possible answer is that each state's own rules apply as to the benefit earned in that state. However, allocating an accrued pension benefit to particular geographical locations is not necessarily an easy task. Suppose, for

vesting provisions, see LANGBEIN \& WoLK, supra note 19, at 132-38; DAN M. MCGILL ET AL., Fundamentals OF PRIVATE PENSIONS 103-09 (7th ed. 1996).

56. Of course, ERISA's vesting rules generate some interpretive issues. See, e.g., Swaida v. IBM Retirement Plan, 570 F. Supp. 482 (1983). On balance, however, those vesting rules are relatively straightforward and administrable, particularly when contrasted with the possibility that each state might have its own disparate vesting scheme.

57. See ERISA $\S 203(\mathrm{a})(2)(\mathrm{A}) ;$ I.R.C. $\S 411(\mathrm{a})(2)(\mathrm{A})$.

58. See ERISA $\S 203(a)(2)(B) ;$ I.R.C. $\S 411(a)(2)(B)$. 
example, that due to poor investment performance, the balance of X's pension account declined while he worked for $\mathrm{Z}$ in state $\mathrm{B}$ but that that account rebounded in state $C$ to the prior level attained in state $A$. Is the portion of X's account attributable to his employment in state $C$ covered by $C$ 's no-vesting rule (on the theory that the appreciation occurred there) or by A's cliff vesting rule (on the theory that $X$ 's time in $C$ merely restored the balance previously earned in $\mathrm{A})$ ? What if $\mathrm{A}$ and $\mathrm{C}$ answer this question differently? An alternative is for the state in which $\mathrm{X}$ begins or terminates his employment to govern his vesting. Suppose, for example, that the laws of the state of termination were to control. Since $\mathrm{X}$ ends his career in $\mathrm{C}$, a state with no pre-retirement vesting, the result would be the forfeiture of the pension rights $\mathrm{X}$ accrued in $\mathrm{A}$ and $\mathrm{B}$. The states might themselves approach this problem differently, with $\mathrm{C}$, as the state in which X's employment is terminated, claiming to control vesting over X's entire pension benefit while $A$ asserts such control as the state of hire, and $B$ claims to govern the vesting of the pension benefits which accrued during X's residence there.

While the Supreme Court has largely framed uniformity considerations from the employer's perspective, ${ }^{59}$ emphasizing the imperatives of plan administration and the cost savings to employers of a single nationwide regime for ERISA-governed benefit programs, a system of decentralized, possibly conflicting state standards might also inhibit employee mobility across state lines. If, for example, state C's no-vesting policy applies to all of X's pension benefits (including those benefits earned in states A and B), $\mathrm{X}$ may be deterred from transferring into state $\mathrm{C}$ since doing so would retrospectively deprive him of vesting rights he earned in $A$ and $B$.

Generalizing from this example, in public choice terms, ERISA embodies a compromise: Multistate employers are freed from different, potentially inconsistent state regimes in the design and administration of their retirement and fringe benefit plans. In policy terms, the logic of national uniformity is that decentralized, potentially conflicting state systems of regulation impose higher transactions costs on interstate employers than does a single nationwide scheme and that such decentralized systems potentially impede the mobility of employees across interstate boundaries.

The case for national uniformity is strongest when, as in this example, the regulation is of retirement income. Since such income is earned cumulatively over the course of an employee's career, the complications of a state-based regime would be great if the employee spent his career in different states. Under a state-based system, the mobile employee would be subject to different, possibly inconsistent, rules for the pension benefits he accumulates over time.

59. See infra notes 53 - 54 and accompanying text. Justice Thomas's Moran dissent also discusses "uniform administration of employee benefit plans." Moran, $122 \mathrm{~S}$. Ct. at 2174 (Thomas, J., dissenting). 
On the other hand, the case for national uniformity is weaker for most fringe benefits since they are not cumulative entitlements that an employee carries from state to state. Rather, such benefits are current emoluments that can more easily be altered when the employee moves across state boundaries. A possible analogy is to different states' rules for workers' compensation and unemployment insurance. No insuperable conflict of law issues arise in these contexts: As a matter of plan administration, employers have learned to live with considerable state-by-state variation in these programs. ${ }^{60}$ There is, moreover, no particular reason to believe that employees are inhibited in their job mobility by differences in states' unemployment and workers' compensation programs.

In the context of a PBR, the questions then become: Is employer-provided health care like retirement income, where the case for national uniformity is strong, given the cumulative nature of employees' rights to such income? Or is employer-provided health care more like unemployment and workers' compensation, historically regulated by the states?

Offsetting the benefits of uniformity are the classic arguments for decentralized regimes: the desirability of experimentation and the accommodation of diverse preferences. In 2003, the case for local experimentation in the regulation of health care rests upon the rapid pace of change in medical technology and practice. In an environment of such rapid change, some states can respond more readily to new developments than can the larger, less supple federal government. States choosing to experiment can generate important data for the states holding back. Failure is limited to the states which elect to experiment. ${ }^{61}$

Suppose, for example, that a new technology is developed to cure cancer, and its proponents claim that technology can allow treatment on an out-patient basis in lieu of traditional surgery and overnight hospitalization. Under a system of decentralized regulation, one or more states might test the new technology by eliminating minimum hospital stays for cancer patients receiving it. If the test proves productive, other states may emulate it. If experience discredits the new technology, the failure would be limited to the states which experimented.

Suppose, in contrast, that a federal PBR mandates on a national basis minimum hospital stays for cancer patients. Under such circumstances, experimentation with the new technology is less likely to occur since the entire nation

60. Different states' worker compensation programs vary significantly as to eligibility for benefits and levels of benefits. See, e.g., U.S. DEP'T OF LABOR, STATE WORKERS' COMPENSATION LAWS (1992). The same is true of states' unemployment insurance laws which utilize a range of formulas for different benefit levels. See, e.g., U.S. DEP'T OF LABOR, COMPARISON OF STATE UNEMPLOYMENT INSURANCE LAWS (1999). As noted in the text, multistate employers have adapted to these state-by-state differences with no apparent difficulty.

61. A panel of health care experts appointed by the Institute of Medicine of the National Academy of Sciences recently highlighted the value of state experimentation as to health care. See Robert Pear, U.S. Urged To Test Solutions To a 'Crisis' in Health Care, N.Y. TIMES, Nov. 20, 2002, at A20. 
would be governed by a single standard.

In response to these concerns, a federal PBR could be designed with an administrative waiver provision allowing states to ask permission from the federal government to pursue new standards and practices. However, such a waiver system would be less likely to encourage experimentation than would a decentralized regime under which states can proceed on their own. Moreover, a waiver system would undermine the justification of a federal PBR as establishing national uniformity. In short, modern medical care presents a compelling case for the states as Brandeisian laboratories of experimentation. ${ }^{62}$

Reinforcing the case for state regulation of health care as encouraging experimentation is the desirability of responding to diverse preferences in health care. Many decisions in the regulation of health care are matters of choice. When preferences are varied, decentralized decisionmaking permits greater accommodation of those preferences. ${ }^{63}$

Consider, for example, section 4-10 of the Illinois HMO statute at issue in Moran. Section 4-10's independent review procedure is not the only plausible response to the problem of medical disagreements between HMOs and the patients they serve. Some states, for example, might prefer permanent commissions to which disgruntled patients like Mrs. Moran can bring their grievances. Another possible approach to patient-HMO conflict is to eschew any kind of administrative or ADR-type process and to send patients directly to court with their complaints. ${ }^{64}$

Insofar as majorities in different states prefer different approaches, statebased regulation enhances overall welfare, letting the legislature of state A enact the preferred alternative of the residents of that state while the legislature of

62. Justice Brandeis coined this now-celebrated metaphor in his dissent in New State Ice Co. v. Liebmann, 285 U.S. 262, 311 (1932). Some of the most interesting legal scholarship being produced today addresses the question of federalism in constitutional terms, i.e., the extent to which the U.S. Supreme Court has and is correct to protect state autonomy judicially. That discussion necessarily focuses in part upon the benefits and costs of decentralized decisionmaking. One can agree that (in contrast to a uniform national standard) state-based regulation of medical care beneficially encourages experimentation and accommodation of local preferences without also believing that the Court should aggressively protect the states from perceived encroachments on their spheres of autonomy. For recent contributions to this growing body of legal scholarship, see Marci A. Hamilton, Why Federalism Must Be Enforced: $A$ Response to Professor Kramer, 46 VILlanova L. REV. 1069 (2001); John O. McGinnis, Reviving Toqueville's America: The Rehnquist Court's Jurisprudence of Social Discovery, 90 CAL. L. REV. 487, 507-26 (2002); Lynn A. Baker \& Emest A. Young, Federalism and the Double Standard of Judicial Review, 51 DUKE L. J. 75 (2001).

63. Contemporary discussion of the accommodation of diverse preferences starts with Charles Tiebout's 1956 article, one of the few academic articles which truly deserves to be called seminal. Charles M. Tiebout, A Pure Theory of Local Expenditures, 64 J. POL. ECON 416 (1956). For a minute sampling of the discussion precipitated by Tiebout's article, see William A. Fischel, Municipal Corporations, Homeowners and the Benefit View of the Property Tax, in PROPERTY TAXATION AND LOCAL Government FinanCe 33 (Wallace E. Oates ed., 2001); Edward A. Zelinsky, Metropolitanism, Progressivism, and Race, 98 CoLUM. L. REV. 665 (1998).

64. In effect, the Moran dissenters would have declared this to be the national rule since, under their analysis, after exhausting her internal claims remedies under ERISA section 503, Mrs. Moran would have been required to sue per ERISA section 502 . 
B can adopt another approach favored by B's residents. In contrast, with a single national standard, the residents of one (perhaps both) of these states would be saddled with a federally-imposed standard their legislators would not adopt for them.

In light of the foregoing, it is tempting to characterize PBR proposals as posing a trade-off between the benefits of national uniformity (lower transactions costs for interstate employers and unimpeded worker mobility between states) and the advantages of state-based regimes (flexibility to experiment and the accommodation of local preferences). However, a final consideration tips the scales: Congress will not pass PBR legislation which is uniform throughout the nation.

The House and Senate versions of PBR legislation in the 107th Congress, had they been enacted into law, would have authorized states to exceed (but not lower) the federal standards embodied in such legislation. ${ }^{65}$ Since states would have been permitted to augment federal standards, such legislation would have created a federal floor for medical care, not national uniformity.

To return to the cancer example, the PBR legislation approved by the House would have guaranteed a breast cancer patient a minimum hospital stay as agreed upon by the patient and her doctor. ${ }^{66}$ States could not have capped that minimum standard (to experiment with new treatments or otherwise) but would have been free to provide greater guarantees than those established by federal law.

The congressional decision to permit states to exceed the standards embodied in federal PBR legislation was no inadvertent or minor decision that slipped through the legislative process. Rather, in the very public and contentious deliberations in which the 107th Congress debated PBR proposals, it was loudly argued that such proposals could dilute patients' protections in those states which had enacted more stringent standards than the standards embodied in the proposed federal legislation. ${ }^{67}$ This argument proved persuasive and led, in both the House and the Senate, to the transformation of PBR legislation from a statement of national uniform standards into a federal floor that the states would have been free to augment (but not reduce).

There is no reason to believe that the politics or policy considerations that controlled in the 107th Congress will not also control in the 108th. The upshot is that PBR legislation will not establish national uniformity but merely a fed-

65. See, e.g., H.R. 2563, 107th Cong. $§ 152(a)(1)$ (2001) (preserving state regulation of health insurance issues as long as such state regulation does not "prevent. . the application of a requirement of" federal law).

66. See H.R. 2563, 107 $7^{\text {th }}$ Cong. $§ 120$ (2001) (guaranteeing breast cancer patients "inpatient coverage.... for a period of time as is determined by the attending physician, in consultation with the patient"). $C f$. ERISA $\S 713$ (requiring post-mastectomy reconstructive surgery).

67. See, e.g., Karen Hosler, Marylanders Could Lose Under Federal HMO Bill; State Insurance Chief Sees Rights in Danger, BALT. SUN, June 22, 2001 at $1 \mathrm{~A}$. 
eral floor.

Thus, the defense of PBR proposals ultimately rests upon the desirability of such a floor. The classic argument for federal legislation establishing national minimum standards is that, without such legislation, states engage in the proverbial "race to the bottom." In the legal academy, the seminal analysis along these lines is Professor Cary's argument that state (as opposed to federal) regulation of corporate governance leads the states to compete with one another to dilute shareholder rights in order to attract corporations to incorporate in the competing states. ${ }^{68}$ Professor Cary's thesis has provoked considerable response over the years, much of it critical. The best-known rejoinder to Professor Carey's analysis remains Professor (now Judge) Winter's argument ${ }^{69}$ that corporations which improperly ${ }^{70}$ diminish shareholder rights by incorporating in states with lax standards of corporate governance will be punished in the marketplace by lower share values as investors move their resources to corporations organized in states with legal regimes more solicitous of shareholder interests. The prospect of such diminished share values will deter incorporation in states with weak protections for shareholders:

A state which rigs its corporation code so as to reduce the yield to shareholders will spawn corporations which are less attractive as investment opportunities than comparable corporations chartered in other states or countries, as well as bonds, savings accounts, land, etc. Investors must be attracted before they can be cheated ....

In a similar vein, others have argued that state (as opposed to federal) environmental laws encourage a race to the bottom as states seek to attract industry by weakening their anti-pollution laws. ${ }^{72}$ Professor Sterk has, in a comparable spirit, argued that some states are, in the name of asset protection, enacting laws that diminish creditors' remedies by impeding access to debtors' assets. ${ }^{73}$ In this case, the perceived race to the bottom reflects the desire to attract investment resources to the financial institutions located in the states enacting these asset protection laws.

For present purposes, the issue is not whether these particular arguments are correct, ${ }^{74}$ but whether they help illuminate the validity vel non of the case

68. William L. Cary, Federalism and Corporate Law: Reflections upon Delaware, 83 YALE L.J. 663 (1974).

69. Ralph K. Winter, Jr., State Law, Shareholder Protection, and the Theory of the Corporation, 6 J. OF LEGAL STUDIES 251 (1977). The Cary and Winter articles have precipitated a cottage industry. Among recent writings on this topic, see Lucian Arye Bebchuk \& Assaf Hamdani, Vigorous Race or Leisurely Walk: Reconsidering the Competition over Corporate Charters, 112 YALE L.J. 553 (2002).

70. According to Judge Winter, shareholders will favor managerial discretion which increases the value of the corporation and its shares. Winter, supra note 69 , at 258-62.

71. Id. at 275 .

72. See, e.g., Kirsten H. Engel, State Environmental Standard Setting: Is There a 'Race' and is It 'To the Bottom'? 48 HASTINGS L.J. 271 (1997).

73. Stewart E. Sterk, Asset Protection Trusts: Trust Law's Race to the Bottom? 85 CORNELL L. REV. 1035 (2000).

74. It is possible, for example, that Professor Sterk is correct to contend that there is a race to the bottom as to asset protection laws but that Judge Winter is correct that competition between states disci- 
for federal PBR legislation as a national floor to prevent a race to the bottom in the regulation of health care.

The race-to-the-bottom scenarios share certain common characteristics, in particular, states attracting resources (corporations, industry, invested assets) by inflicting external costs (weakened shareholder protections, pollution, diminished creditors' rights) upon the residents of other states. Thus, the race to the bottom is initially perceived as essentially costless to the state starting the race since the impact of its actions largely falls outside its borders. Collective action problems arise as other states move (sometimes defensively) to emulate the pattern of enticing (or retaining) resources by imposing costs externally. In all of these cases, the advocates of federal legislation envision the standards such legislation would create as abating the states' collective action problems: There can be no pell-mell race to the bottom when a federal floor closes off the bottom.

I am skeptical that such a race exists for medical care or is likely to exist in the future. Indeed, these examples illuminate the weakness of the race-to-thebottom argument as to health care and thus suggest that there is no need for PBR legislation to establish a national floor for health care. Whatever incentives a state might have to lower health care standards to attract employers, the impact of such lower standards is not externalized but, rather, falls internally upon the state and its residents in a highly visible manner. Delaware's allegedly lower standards of shareholder rights and creditor remedies largely impact on persons outside of Delaware, that is, corporate shareholders and large creditors (most of whom reside outside Delaware). On the other hand, Delaware's regulation of health care impacts principally the people of Delaware and affects them with great immediacy. An HMO's denial of medical services is a visible (and often traumatic) experience for the HMO participant denied coverage.

In the regulation of health care, if there is a race, it is a race to the top as states increase, not diminish, the protections of state law for HMO participants. $^{75}$ As noted above, ${ }^{76}$ in discussion of a federal PBR in the 107 th Congress, a crucial factor was the argument advanced by many states that their respective standards are more stringent than the rules embodied in the proposed federal law. Whatever the merits of these heightened state standards, they suggest that there is no race to the bottom necessitating a federal floor for health care legislation.

plines states from improperly diminishing shareholders' rights.

75. See, e.g., Rush Prudential HMO, Inc. v. Moran, 122 S. Ct. 2151, 2161 (2002) (observing that "at least" forty (40) states "regulate HMOs primarily through the States' insurance departments"); Alan Ehrenhalt, The Monkey or the Gorilla?, GoVERNING, July, 2002 at 6, 8 (noting that states "passed laws protecting patients' rights and monitoring HMO abuses (with a fair degree of success)"); Peter Landers \& Amy Dockser Marcus, You Can Make Them Pay, WALL ST. J., Sept. 17, 2002, at D1 ("But a backlash against health insurers has led many states to pass laws setting up external review panels and requiring insurers to adopt in-house appeal procedures.").

76. See discussion supra note 67. 
Confirming this analysis is the widely held belief that, in practice, the PBR bills approved by the House and Senate in the 107th Congress would have made minimal difference in the day-to-day operations of many HMOs. ${ }^{77}$ That consensus suggests that there is no race to the bottom in the states' regulation of health care but that federal PBR legislation would at best duplicate prevailing state standards. ${ }^{78}$

In short, whatever the merits in other contexts of arguments that the states' race to the bottom necessitates a federal floor, there is no evidence of such a race in the health care setting. There is, moreover, no reason to believe such a race will develop since the impact of lower state standards for medical care is not exported. Rather, it falls quite visibly on the residents (and voters) of the state reducing its standards. And if there is no compelling justification for a federal PBR as a floor, there is no compelling justification for a federal PBR. ${ }^{79}$

77. See, e.g., Charles Omstein, Adverse Reaction: Bad Image, High Prices Make Drug Companies, Not HMOs, Chief Target of Legislators, Dallas MORNING NEwS, Jan. 14, 2001, at $1 \mathrm{~J}$ ("Since the debate first began, though, the HMO landscape has changed so much that a patients' bill of rights would mean little, some experts say. State laws, court rulings and relaxed HMO rules have achieved much of what sponsors wanted.").

78. And such duplication, I note below, comes with its costs in terms of complexity and inflexibility.

79. While I have, in the text, addressed the three strongest arguments for a federal PBR - the existence of an ERISA-created regulatory gap, the advantages of national uniformity in the regulation of health care, and the need for a federal floor for such health care - three other arguments might be advanced for such legislation. While these arguments do not merit full discussion in the text, I want to mention them briefly.

Several readers of earlier drafts of this paper suggested that a federal PBR might provide a safeguard against the possibility that the Supreme Court will revert to its broader, Shaw-based understanding of ERISA preemption and thereby reopen the regulatory gap apparently closed in Pegram and Moran. I find this a remote contingency, insufficient to justify the costs of a federal PBR. Even more importantly, if Congress wants to guarantee that there is no ERISA-created regulatory gap, it can do so without a federal PBR. Since ERISA section 514 is the statutory basis for any such gap, Congress can, as noted in the text, repeal or amend section 514 to make clear that state laws relative to HMOs are not preempted.

Another reader of an earlier draft suggested that a federal PBR might be a step towards some kind of universal medical care program. Whatever the logic of such a program, it is not advanced by a PBR that simply mandates the kind of medical care that must be given to those who already have medical coverage. PBR legislation would not extend medical coverage to anyone not already covered.

See, e.g., President George W. Bush, Principles for a Bipartisan Patients' Bill of Rights, Address at the American College of Cardiology Convention (Mar. 21, 2001), available at http://frwebgate6access.gpo.gov/cgi-bin/waisgate.cgi?waisdocID $=276135514164+0+1+0 \mathrm{WAISaction}=$ retreive (A federal PBR should "ensure that every person enrolled in a plan enjoys strong patients protections.") (emphasis added).

Insofar as federal PBR legislation would increase the cost of health care, such legislation might, at the margin, decrease coverage for the employees of small and struggling employers. From this vantage, PBR legislation would reduce, rather than extend, employer-provided health care.

Finally, other readers of earlier drafts wondered whether a federal PBR can be justified as overriding the decisions by the relative handful of state legislatures which have, to date, not passed their own laws governing HMOs and other managed care providers. Conceivably, given the legal uncertainty surrounding ERISA preemption, some of these legislatures were deterred from adopting such laws. In the wake of Moran and its green light for state HMO legislation, some of these states might now emulate the vast majority which had earlier adopted laws governing managed care providers.

To the extent that some states have elected to eschew legislation regulating HMOs and other managed care providers, it is difficult to see why the federal government should override that decision. 
Moreover, a federal PBR should not be dismissed as harmless symbolism since such legislation, if enacted into law, would inflict two kinds of costs on an already burdened medical system. First, a federal PBR would engender legal and administrative complexity as lawyers, courts, doctors, and health care decisionmakers would be forced to grapple with a new set of detailed statutory provisions. Second, a federal PBR would reduce, if not eliminate, states' flexibility to innovate and experiment with health care, in effect freezing state standards regarding the subjects covered by the federal PBR.

Consider, in this context, the legislation passed by the House in the 107th Congress, particularly the portion of such legislation that would have mandated procedures for resolving disputes between patients and health care providers. ${ }^{80}$ This legislation is daunting in its detail, dictating with great specificity the procedures to resolve patients' initial claims for treatment, internal appeals processes for addressing patients' complaints unresolved by those initial procedures, and, finally, external appeals processes for adjudicating disputes persisting after the completion of the internal appeals procedure. Moreover, the legislation passed by the House (since it was intended to serve as a federal floor) would have required the assessment of each state's equivalent statutory provisions to determine if such state provisions were "substantially compli[ant]" with the federal rules. ${ }^{81}$ If so, in that state, its law — not the federal statute - would govern.

This scheme, enacted into law, would engender conflict and uncertainty for judges, lawyers, physicians, and other health care providers, adding to the cost of health care.

At the end of the day, when it is finally determined which state statutes substantially comply with (and thus displace) federal law, states will be inhibited from altering their respective statutes since such alteration would raise the compliance issue all over again. Moreover, changes to the federal PBR will not be obtained easily. ${ }^{82}$ The upshot is that the states, far from being laboratories of experiment, will be frozen into existing patterns. ${ }^{83}$

In the final analysis, then, a federal PBR would generate cost without benefit. At the margin, that cost would cause smaller and struggling employers to conclude that medical coverage for their employees is not economically viable.

To summarize: Federal PBR legislation would neither fill an ERISAcreated regulatory gap (since there is no such gap under the Court's current,

80. See H.R. 2463, 107th Cong. (2001) $\S \S 102-4$.

81. Id. at $\S 152$ (b).

82. Judge Winter expresses similar concern about a federal corporation law. See Winter, supra note 69 , at 291 ("Moreover, once federal legislation is enacted, it will be very difficult to correct no matter how wrong it may be.").

83. Professors Epstein and Sykes express reservations about a federal PBR in similar terms. See Epstein \& Sykes, supra note 48, at 659 ("Our instinct is that a period of experimental reform at the state level certainly makes sense before any blanket policy is mandated nationally...."). 
more restrained understanding of ERISA section 514) nor provide national uniformity (even assuming such uniformity is desirable). As, at best, a floor underneath states' regulation of health care, a PBR would respond to a nonexistent problem (a race to the bottom in health care which has not occurred and is not likely), while generating unnecessary complexity in the law governing health care and inhibiting the states from experimenting and innovating.

\section{The UNREgulated Status of SELF-Funded Plans UNDER ERISA}

While there is no convincing case for a federal PBR, there is a tenable argument for amending ERISA section 514 to permit the states to regulate employers' self-funded medical care. ${ }^{84}$ Although the arguments are closely matched, on balance, I conclude that Congress should, in the interests of parity, amend section 514 to permit states to extend their regulation of insurance (including HMOs) to include employers' self-financed health care plans. Without such amendment of section 514, the regulatory gap persists in regard to employers' self-funded plans administered without the participation of an insurance carrier. Closing that gap, by amending section 514, would enlarge the compass of state regulatory authority and thereby permit the states to place on equal footing both self-funded employer plans and employer plans using the products and services of the insurance industry, including HMOs.

As noted earlier, ERISA has always permitted states to regulate insurance. ${ }^{85}$ However, in the so-called "deemer clause," Congress decreed that state regulation of insurance does not extend to employer plans themselves. Specifically, ERISA section 514 precludes a state from classifying an employer's plan as insurance, subject to state regulation, since no plan may "be deemed to be an insurance company or other insurer" "for purposes of any law of any State purporting to regulate insurance companies [or] insurance contracts." ${ }^{, 86}$ Under this statutory scheme, states may reach plans indirectly by regulating the insurance they purchase or the insurers administering such plans. However, states are powerless as to employers' self-funded plans since states may not regulate plans directly and have no indirect access to such uninsured plans because such plans, by design, do not purchase insurance or otherwise use the services of an insurer.

In the world before managed care, this statutory scheme gave states the ability to regulate the content of employer-provided medical care when employers purchased then-standard indemnity policies. By regulating the contents of such policies, states (although they could not regulate plans directly) could

84. I prefer the repeal of section 514. See Zelinsky, Reasoned Textualism, supra note 20, at 863; Zelinsky, Overview, supra note 20, at 12-18. Since there is no reasonable prospect of such repeal in the immediate future, the discussion at this point assumes section 514 as permanent.

85. See discussion supra Part II.

86. ERISA § 514(b)(2)(B). See also Moran, 122 S. Ct. at 2162 n.6. 
effectively govern the coverage employers purchased under such policies. However, if employers eschewed insurance and instead self-financed their medical plans, the states were (and still are) precluded by the deemer clause from regulating such plans since no insurance product or company is involved and since the deemer clause prevents the states from classifying plans themselves as insurers, subject to state insurance standards. ${ }^{87}$

With the rise of managed care and the consequent decline of traditional indemnity coverage, there was, as we have seen, a reasonable concern that HMOs operated in an ERISA-created regulatory gap. ${ }^{88}$ But Moran has now dispelled this concern by classifying HMOs as insurers, amenable to state insurance regulation. Thus, today, if an employer engages an HMO to provide medical care for employees or (as is less frequently the case ${ }^{89}$ ) if an employer purchases traditional indemnity coverage for its employees, the health care the employer offers is subject to state regulation since the state can regulate the HMO or indemnity policy, although not the plan itself.

However, if the employer eschews both managed care and indemnity contracts and instead self-funds medical coverage for employees, the deemer clause still places that self-funded plan beyond state and federal regulation. Thus, as to self-funded plans, the ERISA-created regulatory gap persists since state insurance legislation cannot reach these plans (the deemer clause prevents that) and there is no federal regulation of the content of such self-funded plans. $^{90}$

Consequently, in a post-Moran world, the employer has essentially three means by which it may offer its employees health care. The employer can acquire a traditional indemnity policy subject to state regulation since ERISA permits states to regulate insurance; the employer can enroll its workers in an HMO or similar managed care organization, also subject to state regulation since the Moran Court has now held HMOs and similar providers to be insurers, governable by state law; or the employer can eschew these state-regulated alternatives and instead self-fund its employees' medical expenses. Under this last option, the state can regulate the plan neither directly nor indirectly since no insurance product or service is purchased.

The IRS has recently given such self-funded plans a boost. Specifically, the IRS has addressed the tax status of employer-financed "health reimbursement

87. See Metropolitan Life Ins. Co. v. Massachusetts, 471 U.S. 724, 747 (1985) ("We are aware that our decision results in a distinction between insured and uninsured plans, leaving the former open to indirect regulation while the latter are not. By so doing we merely give life to a distinction created by Congress in the 'deemer clause' ....").

88. See discussion supra notes 21-32 and accompanying text.

89. Moran, $122 \mathrm{~S}$. Ct. at 2161 ("[I]n recent years, traditional 'indemnity' insurance has fallen out of favor.").

90. The closest to such substantive regulation is the nondiscrimination rule for self-funded plans provided by the Internal Revenue Code. See I.R.C. $\$ 105(\mathrm{~h})$. 
arrangements" (HRAs), plans under which the employee is reimbursed for medical outlays that the employee makes for himself and his dependents, with unused funds carried over for reimbursement in the future. ${ }^{91}$ Most importantly, properly structured HRAs, the IRS concluded, can qualify for favorable tax treatment under Internal Revenue Code sections 105(b) and 106. This means that neither the existence of the HRA nor a medical reimbursement from the HRA will generate income for the covered employee. Such favorable tax treatment places HRAs on par with alternative means of financing medical care.

Insofar as HRAs are administered by insurance companies, those companies (and, thus, indirectly the programs they administer) are subject to state regulation. Similarly, if HRAs are combined with major medical or highdeductible insurance, that additional component of the employer's health care coverage is subject to state insurance regulation. ${ }^{92}$ However, insofar as standalone HRAs are established and administered without the participation of an insurance company, such HRAs, as employer-financed, noninsured devices, can be used to exploit the regulatory gap which originally animated support for a federal PBR.

Suppose, for example, that an employer is concerned about rising health care costs since the employer has been informed that premiums are increasing under either traditional indemnity or HMO coverage. Suppose further that the employer (individually or in concert with others) asks the insurer to scale back coverage to reduce costs. In some respects, the insurer may be able to comply with this request. However, to the extent particular services are state-mandated, the insurer cannot. ${ }^{93}$

Assume, for example, that the employer asks for a reduction in the mental health services covered under either the traditional indemnity policy or HMO contracts. To the extent those services are required by state regulation, the insurer cannot comply. Or suppose that the employer asks for a reduction in minimum hospital stays for particular conditions. Again, to the extent these minima are state-imposed, the insurer has no leeway to accede to the employer's request.

91. Rev. Rul. 2002-41, 2002-28 I.R.B. 75; I.R.S. Notice 2002-45, 2002-28 I.R.B. 93. See also Stanley D. Baum, Health Reimbursement Arrangements - Who will Benefit from the Service's Newest Healthcare Plan?, 97 J. TAX 162 (2002); Natalia Radziejewska, Congress, Healthcare Vendors Welcome IRS Decision on Health Reimbursement Accounts, 2002 TAX NOTES TODAY 133-7 (July 11, 2002).

92. The examples in Revenue Ruling 2002-41 and I.R.S. Notice 2002-45 involve HRAs coupled with major medical or high deductible coverage. Logically, however, nothing prevents an HRA from being the employer's sole health plan, although, as discussed in the text, I am skeptical that this will often happen in practice.

93. Many observers attribute the high cost of insurance policies and resulting reductions in insurance coverage to the features mandated by state law. See, e.g., Amy Finkelstein, MINIMUM STANDARDS AND INSURANCE REgUlATION: EVIDENCE FROM THE MEDIGAP MARKET, 4 (Nat'l Bureau of Econ. Research, Working Paper No. 8917, 2002) (arguing that mandated minima for individual Medigap policies result in "substantial declines in insurance coverage"). See also, Why You Can't Buy Insurance, WALL ST. J., Oct. 1, 2002, at A20. 
The employer does have a path around these state-mandated minima: a selffunded plan. Assume, for example, that the employer rejects both traditional indemnity coverage and HMO participation and instead establishes an HRA for each employee, financed and administered by the employer without the involvement of an insurer and without any major medical or similar coverage which is triggered when the employee's reimbursable limit is reached. Under the HRA, the employee can spend his allocation for whatever medical services he wants and will be reimbursed up to the amount allocated to him. However, when the employee's HRA allocation is depleted, the employer's financial commitment ends until the next period. ${ }^{94}$

In this fashion, the employer can cap its health care expenditures at a level less than the projected premiums for state-regulated indemnity or HMO coverage. The employees, while free to allocate their respective HRA allocations as they choose, ${ }^{95}$ will not receive the state-required coverage they would have received under either of the insurance alternatives.

To continue our hypothetical, suppose that the employer has been paying annually $\$ 10,000$ per employee for HMO coverage. Suppose further that the employer has been informed that, for the forthcoming year, the premium will rise to $\$ 12,000$ under either the traditional indemnity or the HMO alternative. The employer could (as many employers do) shift this increase, in whole or in part, to the employee. Suppose instead that the employer foregoes either of the state-regulated alternatives and instead establishes as its sole health plan an employer-administered HRA for each employee with an annual cap of $\$ 9,500$, calculating that the remaining $\$ 500$ will cover the employer's costs of implementing the HRA arrangement.

In this way, the employer has limited its medical costs to the preexisting level ( $\$ 10,000$ per employee per year) and has effectively rebuffed statemandated services for its employees. While these employees have, in this example, avoided absorbing any of the additional premiums associated with indemnity or HMO coverage, these employees have also lost the protection of the state-required services since the employer's plan no longer purchases a stateregulated insurance product. If, in this example, an employee wants health services after exhausting his HRA entitlement, he must wait until the following year and the replenishment of that entitlement. If enrolled in a state-regulated HMO or covered by a state-regulated indemnity policy, the employee would be entitled to such services if they were state-mandated.

Should we be concerned about this hypothetical employer's avoidance of state regulation through the use of self-funded and administered medical care?

94. Conversely, unused amounts in an HRA can be carried over to the next period for medical reimbursement then.

95. Provided that HRA amounts must only be used for medical expenses and cannot be taken in cash or in other fringe benefit forms. 
Three arguments suggest that we should not. First, among smaller employers, the scenario I have postulated-employers controlling costs by eschewing all state-regulated forms of medical care and instead solely self-funding and selfadministering-is not likely to be widespread. More likely for smaller employers are the scenarios, outlined in Rev. Rul. 2002-41 and I.R.S. Notice 2002-45, under which HRAs are coupled with insurance coverage. Under this latter arrangement, the employee uses the HRA for minimal, routine care but triggers insurance coverage in the event of major illness or the exhaustion of his HRA limit.

Likewise, it is probable that smaller employers will hire insurance companies to administer HRA programs rather than administer such programs inhouse. Insurers will often bring economies of scale to HRA administration and will thus implement HRA plans more cheaply than could small employers themselves. Insurers can also utilize economies of scale as purchasers, negotiating with vendors to obtain bulk discounts for HRA participants. For example, an insurer may be able to negotiate lower drug prices for the employees covered by the HRA plans the insurer administers.

Either way, the involvement of a state-regulated insurer, as a plan administrator, as the vendor of supplementary insurance coverage, or as both, gives the state a regulatory handle to protect employees-if the state so desires. ${ }^{96}$ Thus, for example, state law might forbid insurers from administering HRAs unless certain minimum standards are met. Similarly, state regulations might proscribe insurers from issuing major medical or high deductible policies coupled with HRAs unless specified criteria are satisfied. In short, it is likely to be rare for a small employer offering its employees health care coverage to eschew all connection with insurance products and the insurance industry and thereby avoid state regulation by the use of self-funded and administered health care. More likely, when small employers establish HRAs, the states will be able to regulate indirectly via their control over the insurance policies coupled to HRA programs and/or the states' regulation of the insurers administering such HRA programs on behalf of such employers.

A second reason for viewing with equanimity employers' abilities to avoid state regulation by self-funding and self-administering their health care programs is that larger employers offering self-funded medical care for their employees will often, for competitive reasons, match state-mandated standards for insurance products - even though they are not legally obligated to do so. ${ }^{97}$

96. Moran also suggests the possibility that a "pure administrator", independent of the "insurance industry" and providing "only administrative services for a self-funded plan," might avoid state insurance regulation (since there is no risk-shifting or other insurance-type involvement), while being protected from other forms of regulation (since ERISA preemption under section 514(a) applies). 122 S.Ct. at 2162-64.

97. See, e.g., Dennis K. Schaeffer, Insuring the Protection of ERISA Plan Participants: ERISA Preemption and the Federal Government's Duty To Regulate Self-Insured Health Plans, 47 BUFF. L. REV. 


\section{Patients' Bill of Rights}

While many employees and prospective employees may not be competent to evaluate employers' health care coverage, ${ }^{98}$ in large businesses, enough workers may be capable of such evaluation that such employers may conclude that they must meet the coverage offered by other firms using state-regulated insurance-or risk having these more knowledgeable employees migrate to firms providing better care to their work forces. Moreover, corporate managers, who themselves receive self-funded, employer-provided medical coverage, may believe it to be in their personal interests for such self-funded plans to match the state standards for insured arrangements.

A final reason that self-funding might be viewed as benign is that that ability might be considered a safety valve that, in the face of rising medical costs and overregulation, permits employers to control health care expenses and thus continue to offer such care. Consider, again, the alternatives of the employer confronted with price increases for his state-regulated alternatives, i.e., traditional indemnity or HMO coverage. The employer could stay with either or both of those alternatives and pass the additional cost to his employees in the form of increased co-pay requirements. Or the employer could drop health care coverage altogether. ${ }^{99}$

In light of those possibilities, a self-funded plan (in the form of an HRA or otherwise) might be preferable.

More generally, if employers have an exit option in the form of self-funded plans, insurers are encouraged to control the costs of their products. Moreover, regulators and legislators are encouraged to scrutinize more closely their regulation of insurance (including HMOs) since overregulation will send employers to the unregulated choice of self-funded care. Insofar as regulation reflects, in public choice terms, the influence of provider groups ${ }^{100}$ successfully demand-

1085,1104 (1999) ("data from the early 1980 s . . indicates that two out of three self-insured employers in New York provided plan participants with all state-mandated benefits. ..").

98. As I discuss infra, employees' inability to assess and thus shop for health care coverage is a principal argument for state regulation on such employees' behalf.

99. A point Justice Thomas noted in his Moran dissent ("no employer is required to provide any health benefit plan under ERISA..."). Moran, 122 S. Ct. at 2179 (Thomas, J., dissenting).

100. Consider, for example, sections 115,116 and 132 of H.R. 2563 as approved by the House of Representatives in the 107 th Congress. Section 115 would have prevented group health plans and health insurance issuers from requiring the certification of "a primary care provider" before a female patient could utilize the services of an obstetrical or gynecological provider. Section 116 would have mandated that plans and insurance policies requiring "the designation of a participating primary care provider" permit the designation of participating pediatricians as children's primary care providers. Section 132(a) would have prevented group health plans and health insurance issuers from "discriminate[ing]" "solely on the basis of" a particular health care provider's license. Sensible policy rationales can be mustered for all of these rules. However, one need not be a devotee of public choice theory to also see the possibility that these rules reflect political pressure from pediatricians, ob/gyn practitioners, and other health care providers seeking to protect the value of their respective licenses.

Also consider states" "any willing provider" statutes. See supra note 49 and accompanying text. As a matter of policy, both the supporters and the opponents of such statutes invoke plausible arguments. Again, however, even one generally skeptical of public choice theory can see the possibility that these statutes reflect the political influence of the provider groups the statutes protect. 
ing that their services be required by law, the option of self-funded health care disciplines the political process by giving employers a means of providing health care untrammeled by the political influence these groups exercise via the insurance-regulation and state legislative processes.

Indeed, there is much irony in the possibility that employers might turn to self-funded medical arrangements to escape the costs associated with overregulated HMO coverage: HMOs (and other managed care providers) were themselves originally embraced as cost-saving alternatives to traditional indemnity coverage.

It is, however, plausible to start from the premise that state regulation of traditional indemnity and HMO coverage is largely sensible. ${ }^{101}$ Employers and employees may be inherently poor consumers of insurance and medical care. Insurance and medical care are complex subjects. Acquiring expertise in these areas is expensive, whether such expense takes the form of time and energy to master the details or the money to consult with someone who has. In their choices, purchasers of insurance and medical coverage are, in important respects, nonrepeat players, not experiencing a particular medical problem (and therefore not understanding the problem or its importance) until it is too late to revisit coverage choices made earlier, before the individual knew he would have that specific problem.

Employers and employees may not assess medical risks well. ${ }^{102}$ Imbalances in bargaining power (between employers and employees and between small employers and larger insurers and health care organizations) may bias outcomes in an unregulated marketplace. Selections by employers, employees and health care organizations might generate externalities for government and the community as a whole. If, for example, an HMO does not provide basic immunization for children, the public school system may be required to provide that immunization itself or may be forced to keep nonimmunized children out of school. Either way, the HMO's decision inflicts social cost.

From this vantage, it is troubling that an employer can avoid state regulation by self-funding and administering medical care since the employer thereby skirts a desirable regulatory framework designed to compensate for the inadequacies of private decisionmaking as to insurance and health care. From this perspective, it makes little sense for the nature and quality of the medical treatment received by an employee to depend upon the employer's choice to self-fund or not.

On balance, I conclude that Congress should amend section 514 to permit

101. See, e.g., JACOB S. HACKER, THE DIVIDED WELFARE STATE 180-82 (2002) ("Open any introductory textbook on health economics and you will find a long list of reasons that health care is not like other market goods.").

102. See e.g., Paul Slovic et al., Response Mode, Framing and Information-Processing Effects in Risk Assessment, in Decision MAKING (David E. Belle et al. eds., 1988). 
(but not require) states to extend to self-funded medical plans the states' standards regulating insurance products including HMOs. At one level, such an amendment is antithetical to the premises of a federal PBR since that amendment would expand the scope of state (rather than national) regulation. I expect that some states would use their new authority over self-funded health care arrangements while others, for reasons of policy, politics ${ }^{103}$ or both, would not.

For those favoring, in this arena, decentralized decisionmaking and the accommodation of diverse preferences, the resulting experimentation (some states regulating self-funded plans, some not) would generate useful experience.

There is, in short, a plausible case for amending section 514 to permit states to extend to self-funded plans the states' standards for HMOs and traditional indemnity policies. If members of Congress feel a pressing need to pass legislation labeled as a "patients' bill of rights," such a relatively modest amendment of section 514 could carry that moniker. ${ }^{104}$

\section{CONCLUSION}

A federal PBR is today a program in search of a rationale, legislation which, if enacted, would generate cost without benefit. While a PBR was originally conceived to fill an ERISA-created regulatory gap, there is no such gap under the Court's current understanding of ERISA section 514 and thus no justification for a PBR under this initial, preemption-based rationale. Congress has made clear that a PBR will not provide national uniformity, even assuming such uniformity is desirable. As, at best, a floor underneath states' regulation of health care, a PBR would respond to a nonexistent problem, a race to the bottom in health care that has rot occurred and is not likely to occur. On the downside, a PBR would generate unnecessary complexity in the law governing health care while inhibiting the states from experimenting and innovating.

Perhaps the best scenario for the future is that the political impetus for Congress to pass something called a "patients' bill of rights" will dissipate as

103. Presumably, self-funding employers who do not match state-mandated standards for insurance will oppose the extension to them of those standards. On the other hand, insurers, under the banners of parity and fair competition, are likely to press the states to require self-funding employers to meet the same standards as the insurance industry.

104. If Congress amends section 514 to permit states to regulate employers' self-funded medical plans, Congress might also consider amending section 514 to clarify the status of state laws such as Oregon's Measure 23, which would have established a single state-run health care system. Arguably such a law is ERISA-preempted insofar as it displaces employer-provided medical plans. On the other hand, after Moran, a proposal like Measure 23 might be protected by section 514's exemption for insurance laws since the program Measure 23 would have authorized can be viewed as a state-run insurance scheme.

While I am skeptical as to the merits of such programs, I see no reason for ERISA to block any state experiments along these lines. On Measure 23 and its defeat at the polls, see Andrew Caffrey et al., Voters Reject Initiatives for Big Changes, WALL ST. J., Nov. 7, 2002, at A5; Bernard Wysocki, Jr., Oregon To Vote on Hot-Button Issue of Universal Health Care, WALL ST. J., Oct. 29, 2002, at B1; James Mayer, Oregon Voters Kill Plan for Publicly Funded Health Care, 26 STATE TAX TODAY 448 (Nov. 12, 2002). 
states continue to play their traditional roles as the primary regulators of medical care and insurance. The worst possible scenario is that the 108th Congress, impelled by a political imperative to pass legislation along the lines almost approved in the 107th Congress, will saddle the medical system with unnecessary complexity and inflexibility in the form of federal PBR legislation. And this, ironically enough, will be done in the name of helping the consumers of employer-provided medical care. 